(c) 2003 Blackwell Publishing, Inc.

The definitive version is available at www.blackwell-synergy.com

\title{
Long-term ammonia exposure of turbot: effects on plasma parameters
}

\author{
Person-Le Ruyet $^{\mathrm{a} \star}$ J., A. Lamers ${ }^{\mathrm{bc}}$, A. Le Roux ${ }^{\mathrm{a}}$, A. Sévère ${ }^{\mathrm{a}}$, G. Boeuf ${ }^{\mathrm{ad}}$ and N. Mayer-Gostan ${ }^{\mathrm{b}}$
}

a Laboratoire de Physiologie des Poissons, Ifremer, Centre de Brest, BP 70, 29280 Plouzané, France. b UMR INRA-UNSA 1112 "Rose", Faculté des Sciences, Université de Nice Sophia-Antipolis, Parc Valrose, 06108 Nice Cédex 2, France

c present address: Dept. Pharmacology and Pathophysiology, Utrecht University, PO BOX 80082, 3508 TB Utrecht, The Netherlands.

d present address, Laboratoire Arago, BP 44, 66651 Banyuls-sur-Mer Cédex, France.

*: Author to whom correspondence should be addressed. Tel.: +33 02982243 91; fax: +33 02982243 66; email: jperson@ifremer.fr

\begin{abstract}
Turbot juveniles were exposed to four ammonia concentrations [0.17 (L), 0.34 (M), 0.73 $(\mathrm{MH})$ and $0.88(\mathrm{H}) \mathrm{mg} \mathrm{l}-1 \mathrm{NH} 3-\mathrm{N}]$ for different exposure durations (28 days minimum to 84 days). Their physiological status and growth performances were compared to a control group [0.004 (C) mg l-1 $\mathrm{NH} 3-\mathrm{N}]$. No growth was observed in the $\mathrm{H}$ group, and by day 57, mass increase in the $\mathrm{MH}$ group was only $15 \%$ of that in group C. During the first month growth in the $L$ group was similar to that in control group while it was lower (33\%) in the $\mathrm{M}$ group; afterwards the $\mathrm{L}$ and $\mathrm{M}$ groups had a similar growth (half that of controls). Accumulation of total ammonia nitrogen (TA-N) in plasma was dependent on ambient ammonia concentrations. Plasma urea levels in ammonia-exposed fish were lower, similar or greater than in controls (depending on ammonia concentration or exposure duration). Osmolarity, $\mathrm{Cl}$ and $\mathrm{Na}+$ plasma concentrations were stable in the $\mathrm{L}$ and $\mathrm{M}$ groups. The increases in $\mathrm{Na}+, \mathrm{Cl}-, \mathrm{K}+$ and total $\mathrm{Ca}$ concentrations observed by the end of the experiment in the $\mathrm{H}$ and $\mathrm{MH}$ groups suggest that fish failed to adapt. There was an initial rise in plasma cortisol in all ammonia-exposed groups followed by a return to basal level (1.7-4 $\mathrm{ng} \mathrm{ml}-1)$ in the $\mathrm{L}$ and $\mathrm{M}$ groups. In group $\mathrm{MH}$, plasma cortisol peaked

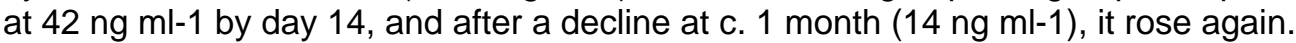

Keywords: chronic toxicity; cortisol; ion regulation; Scophthalmus maximus; total ammonia nitrogen; urea 


\section{INTRODUCTION}

In teleosts, total ammonia nitrogen (TA-N), the sum of $\mathrm{NH}_{3}-\mathrm{N}$ and $\mathrm{NH}_{4}{ }^{+}$, is the prominent form of nitrogenous wastes and may be highly toxic under any conditions leading to marked disturbances in nitrogen excretion, e.g. high environmental ammonia levels, high or low ambient $\mathrm{pH}$, or air exposure (Wood, 1993). In intensive fish farming where fish are held in high stocking densities, a gradual accumulation of ammonia in water may occur, especially when water flow is restricted. The toxicity of ammonia observed in saltwater fish and the factors that influence this toxicity are poorly documented in comparison with freshwater species (US EPA, 1989, 1998). Most published results on the effects of ammonia in seawater fish are restricted to estimations of survival and effects on growth parameters. The 96-h LC50 (lethal concentration for $50 \%$ of the population) was estimated in the range $1.7-2.7 \mathrm{mg} \mathrm{l}^{-1}$ ambient $\mathrm{NH}_{3}-\mathrm{N}$ for seabream, Sparus aurata (L.) and turbot, Scophthalmus maximus (R.) (= Psetta maxima L.), (Wajsbrot et al., 1991; Person-Le Ruyet et al., 1995) and only 0.2-0.7 $\mathrm{mg} \mathrm{l}^{-1}$ ambient $\mathrm{NH}_{3}-\mathrm{N}$ in salmonids (Russo \& Thurston, 1991; Knoph, 1992). The NOEC (noobservable-effect concentration) range for growth was found around 0.05-0.2 $\mathrm{mg} \mathrm{l}^{-1}$ $\mathrm{NH}_{3}-\mathrm{N}$ in 0.3-100 g turbot and seabream (Wajsbrot et al., 1993; Rasmussen \& Korsgaard, 1996; Person-Le Ruyet \& Bœuf, 1998) and around 0.06-0.08 mg l-1 $\mathrm{NH}_{3}-\mathrm{N}$ in 35-600 g Atlantic salmon Salmo salar (L.), (Fivelstad et al., 1995).

The exact mechanisms of toxicity of ammonia, considered as a major neurotoxin in mammals, remain unclear in teleosts (Mommsen \& Walsh, 1992; Tomasso, 1994). Information on the related long-term physiological responses to ammonia exposure are rare in a seawater environment both in marine fish (Rasmussen \& Korsgaard, 1998; Person-Le Ruyet et al., 1997a) and in seawater salmonids (Fivestald et al., 1995; Knoph 
\& Thorud, 1996). When held under high ambient ammonia concentrations, turbot can partly detoxify TA-N loaded in most tissues using the urea production pathway as in many fish species (Wood, 1993; Person-Le Ruyet et al., 1998; Wang \& Walsh, 2000). The gill, largely exposed to water-borne pollutants, is involved in many physiological functions (respiration, acid-base regulation, ions exchanges) and is also the main route for excretion of nitrogenous. Non-specific stress frequently causes osmoregulatory disturbances with a rise in plasma ions and cortisol levels in seawater fish (Wendelaar Bonga, 1997 and Mommsen et al., 1999 reviews) and exposure to high levels of ammonia have been shown to cause stress in different fish species (Tomasso et al., 1981; Spotte \& Anderson, 1989).

The aim of the present study was to examine if long-term exposure to ammonia will impair osmoregulation by checking effects on plasma solute (osmolarity, $\mathrm{Na}^{+}, \mathrm{Cl}^{-}$, $\mathrm{K}^{+}$and total $\mathrm{Ca}$ ) and cortisol concentrations. To our knowledge the time course of these parameters were rarely or never measured in seawater species, during long-term exposure to ammonia. Different concentrations of ammonia were chosen to cover a range that will allow a minimal duration of about one month of exposure as recommended for toxicological studies (Kooijman \& Bedaux, 1996). Thus for the 2 lowest concentrations of ammonia (and control) the experiment lasted 84 days. Although the two other concentrations were lower than the 96-h LC50 some mortality could be expected for the duration chosen (minimal 28 days). Mortality was not analyzed and all the fish withdrawn from the experimental tanks were freely swimming and did not show any external difference from the control fish. The effects on growth and nitrogen end products (TA-N, urea) were also examined. The results will be discussed in relation to growth and physiological disturbances and/or acclimation. 


\section{MATERIAL AND METHODS}

\section{FISH HANDLING AND EXPERIMENTAL PROTOCOL}

The experiment was performed in $1 \mathrm{~m}^{2}$-Swedish-type tanks with a water volume of 350 l. A flow-through method was used with running seawater providing an exchange rate of $100 \%$ per hour in the tanks $\left(5.8 \mathrm{l} \mathrm{min}^{-1}\right)$. The running seawater supply (sand-filtered and aerated, $\mathrm{O}_{2}$ concentration of $7.4 \mathrm{mg} \mathrm{l}^{-1}$ ) limited bacterial contamination and allowed to maintain $\mathrm{O}_{2}$ concentration in the outflow over $6 \mathrm{mg} \mathrm{l}^{-1}$. Temperature and salinity were $17-17.5^{\circ} \mathrm{C}$ and $34-35 \%$ respectively, photoperiod was constant (16 L-8 D) and light intensity at the water surface was $2 \mathrm{~W} \mathrm{~m}^{-2}$. The fish, randomly distributed among five tanks (122 fish per tank), were maintained in the rearing and feeding conditions for 2 weeks before the start of the experiment. They were hand-fed twice a day to apparent satiety. In the basal diet (Person-Le Ruyet et al., 1991) total protein and crude fat content were $60.9 \%$ and $13.9 \%$ of dry matter respectively.

At day 0, 4 fish per tank were sampled, and the initial mean weight was estimated for each tank by weighing individually 35 anaesthetized fish per tank (it takes 35 sec per fish and fish can feed again within $1 \mathrm{~h}$ indicating a low stress level during weighing). There was no statistical difference between fish weight of the 5 tanks (73.4 $\pm 1.4,71.1 \pm 1.3,73.4 \pm 1.8,73.4 \pm 2.2$ and $69.1 \pm 2.1, \mathrm{n}=35)$. One tank was maintained without any exogenous ammonia and served as control (group C). In the other 4 groups, a concentrated solution of $\mathrm{NH}_{4} \mathrm{Cl}$ per nominal concentration was added to the water inflow of each tank by a peristaltic pump (Ismatec ${ }^{\circledR}$ ). The lowest concentration, expected to be around $0.15 \mathrm{mg} \mathrm{l}^{-1} \mathrm{NH}_{3}-\mathrm{N}$, was within the NOEC range (group L); the second one (group $\mathrm{M}$ ) was expected around $0.30 \mathrm{mg} \mathrm{l}^{-1} \mathrm{NH}_{3}-\mathrm{N}$ and these two groups 
and the control were studied until day 84 . The third concentration was expected around $0.70 \mathrm{mg} \mathrm{l}^{-1} \mathrm{NH}_{3}-\mathrm{N}$ and the test lasted 66 days (group $\mathrm{MH}$ ). A fourth concentration, around $0.9 \mathrm{mg} \mathrm{l}^{-1} \mathrm{NH}_{3}-\mathrm{N}$ (group $\mathrm{H}$ ), was also selected but exposure was stopped at day 28. Ambient TA-N and pH (Orion 901 fitted with a Fermprobe ${ }^{\circledR}$ electrode) were measured before feeding in each tank, once a day the first week and every three days afterwards. Ambient $\mathrm{NH}_{3}-\mathrm{N}$ concentrations were calculated using the equation of Johansson \& Wedborg (1980) that gives the $\mathrm{NH}_{3}-\mathrm{N}$ to TA-N ratio as a function of $\mathrm{pH}$, temperature and salinity. Ambient ammonia concentrations are expressed in mg $\mathrm{l}^{-1} \mathrm{NH}_{3}$ $\mathrm{N}$ or in mg $\mathrm{l}^{-1}$ TA-N when compared to blood plasma levels as blood $\mathrm{pH}$ was not measured.

The experiments reported in this paper complied with the Principles of Animal Care of the National Institute of Health (publication no. 86, revised 1985) and the French laws for experiments on animals (decree no. 87-848). First author agreement licence is 006443.

\section{STUDIED PARAMETERS}

Fish were fasted for 24 h before sampling. At regular intervals (day 7, 14, 28, 57, 66 and 84) ten fish per tank were euthanized with a lethal dose of ethylene-glycolmonophenyl-ether ( $3 \mathrm{ml} \mathrm{l}^{-1}$ seawater). These ten fish, first removed from the tank to avoid stress linked to handling, were sampled for cortisol analysis. Then ten other fish per tank were anaesthetized with a lower dose of ethylene-glycol-monophenyl-ether (1.5 $\mathrm{ml} \mathrm{l}^{-1}$ seawater) were sampled for other parameters analysis and killed. In all fish, blood (about $1 \mathrm{ml}$ ) taken within one minute from caudal vessels, was centrifuged immediately and plasma analyses were either performed immediately (TA-N 
concentrations) or later (plasma samples stored at $-25^{\circ} \mathrm{C}$ ). At day 29 and 59, haematocrit was estimated. All fish sampled were individually weighed.

Plasma TA-N concentrations were measured using an enzymatic kit Sigma Diagnostics UV $-170^{\circledR}$ with a precision of $0.01 \mathrm{mg} \mathrm{l}^{-1}$. Osmolarity was measured with an Advanced Instrument osmometer ${ }^{\circledR}, \mathrm{Cl}^{-}$by argentimetric titration with a Radiometer CMT $10^{\circledR}, \mathrm{Na}^{+}$and $\mathrm{K}^{+}$with a Beckman Electrolyte 2 analyzer ${ }^{\circledR}$ and total calcium and urea-N with Sigma Diagnostics kits (total Ca- $587^{\circledR}$, Urea Nitrogen-535 ${ }^{\circledR}$ ). Cortisol concentrations were determined in triplicates by radioimmunoassay (RIA) without extraction as described previously (Lamers et al., 1992). Results were reported in Tables and Fig., only when data for the ten fish were available (owing to the shortage of plasma some measurements are missing).

\section{DATA ANALYSIS}

Results were expressed as mean \pm standard error (n specified) and statistical analyses were conducted using Statistica for Windows. Changes in physiological parameters with ambient ammonia concentration and time of exposure were tested by a two-way ANOVA. Significant ANOVA were followed by a post hoc multiple comparison test (Newmans Keuls). Differences were considered significant at $\mathrm{P}<0.05$. Regression analysis was used to estimate growth rates and plasma TA-N versus ambient TA-N. 


\section{RESULTS}

Constant ambient $\mathrm{NH}_{3}-\mathrm{N}$ concentrations were difficult to maintain during the first week (Fig.1A). However according to recommendations for toxicology studies (US EPA, 1998), all $\mathrm{NH}_{3}-\mathrm{N}$ concentrations tested can be considered acceptable constant levels afterwards. They were $0.004 \pm 0.001 \mathrm{mg} \mathrm{l}^{-1} \mathrm{NH}_{3}-\mathrm{N}$ in group $\mathrm{C}(\mathrm{n}=30), 0.17 \pm 0.01$ in group $\mathrm{L}(\mathrm{n}=30), 0.34 \pm 0.01$ in group $\mathrm{M}(\mathrm{n}=30), 0.73 \pm 0.02$ in group $\mathrm{MH}(\mathrm{n}=28)$ and $0.88 \pm 0.03$ in group $H(n=14)$. The corresponding mean TA-N concentrations were respectively $0.16,5.6,11.4,21.1$ and $27.2 \mathrm{mg} \mathrm{l}^{-1}$. Although the renewal rate of seawater in the tanks was $100 \%$ per hour, a small but constant $\mathrm{pH}$ difference was observed between seawater inflow and fish tanks water whatever ammonia concentration was (Fig.1B). In MH group, pH values increased after day 50 as stocking density decreased (7.97 $\pm 0.02, \mathrm{n}=25)$, but they were not significantly different in C, L, M groups (e. $g$. 7.96 \pm 0.01 in C group and 7.93-7.94 \pm 0.01 in $\mathrm{L}$ and $\mathrm{M}$ groups).

To clarify the presentation, results will be presented separately for, (1) turbot of groups $\mathrm{MH}$ and $\mathrm{H}$ where experiments were the shortest and (2) turbot of groups $\mathrm{L}$ and M) where fish were tested for 84 days. Results will be compared to those of group C. 
Fig. 1. Water $\mathrm{NH}_{3}-\mathrm{N}$ concentrations (A) and water $\mathrm{pH}(\mathrm{B})$ during the experiment in the 5 fish groups: $\mathrm{C}$, 0.004; L, 0.17; M, 0.34; $\mathrm{MH}, 0.73$ and $\mathrm{H}, 0.88 \mathrm{mg} \mathrm{l}^{-1}$ mean ambient $\mathrm{NH}_{3}-\mathrm{N}$ concentrations. Corresponding mean ambient Total Ammonia Nitrogen, TA-N, concentrations are: C, 0.16; L, 5.61; M, 11.42; $\mathrm{MH}, 21.15$ and $\mathrm{H}, 27.20 \mathrm{mg} \mathrm{l}^{-1}$ (temperature, $17-17.5^{\circ} \mathrm{C}$ and salinity $34-35 \%$ ).
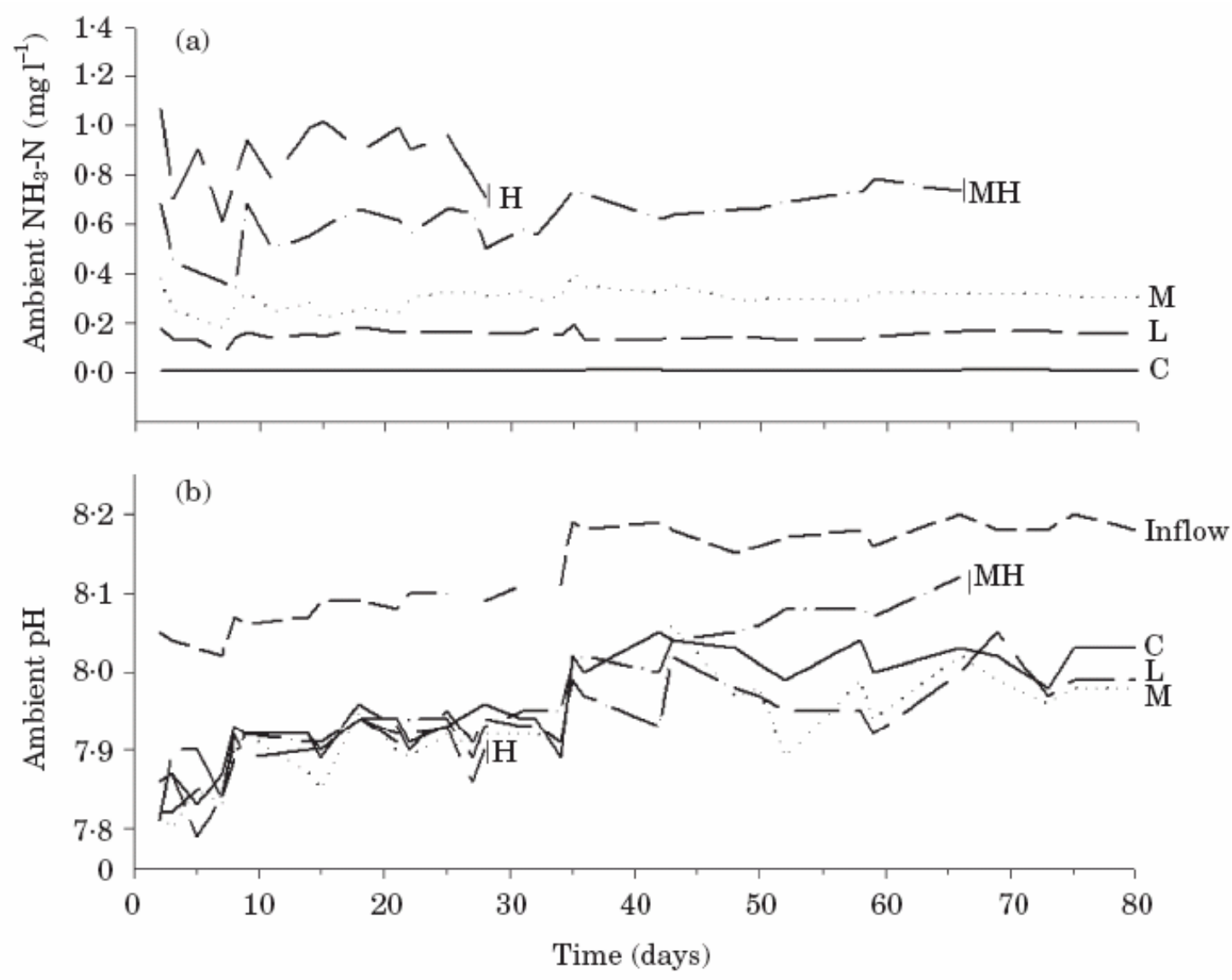

\section{EFFECTS OF AMMONIA EXPOSURES in MH and H groups}

In the two groups of fish there was no obvious sign of stress (no changes in skin color and no behavioral disturbances) and the fish withdrawn for measurements did not show any external sign that could be an indication of pain or suffering. There was no mass increase in group $\mathrm{H}$ (data not shown) by day 28, and mass increase in group $\mathrm{MH}$, by day 57 , was only $15 \%$ of that in group C (Fig. 2). 
Fig. 2. Mass changes over time in $\mathrm{C}$ (?), L (?), $\mathrm{M}$ (?) and $\mathrm{MH}$ (?) groups (C, 0.004; L, 0.17; M, 0.34; $\mathrm{MH}, 0.73 \mathrm{mg} \mathrm{l-1}$ mean ambient NH3-N concentrations). Values are means \pm standard error $(n=10)$. Regression equations are given for two periods of time (day 0-28 and day 28-84) for groups L and $\mathrm{M}$.

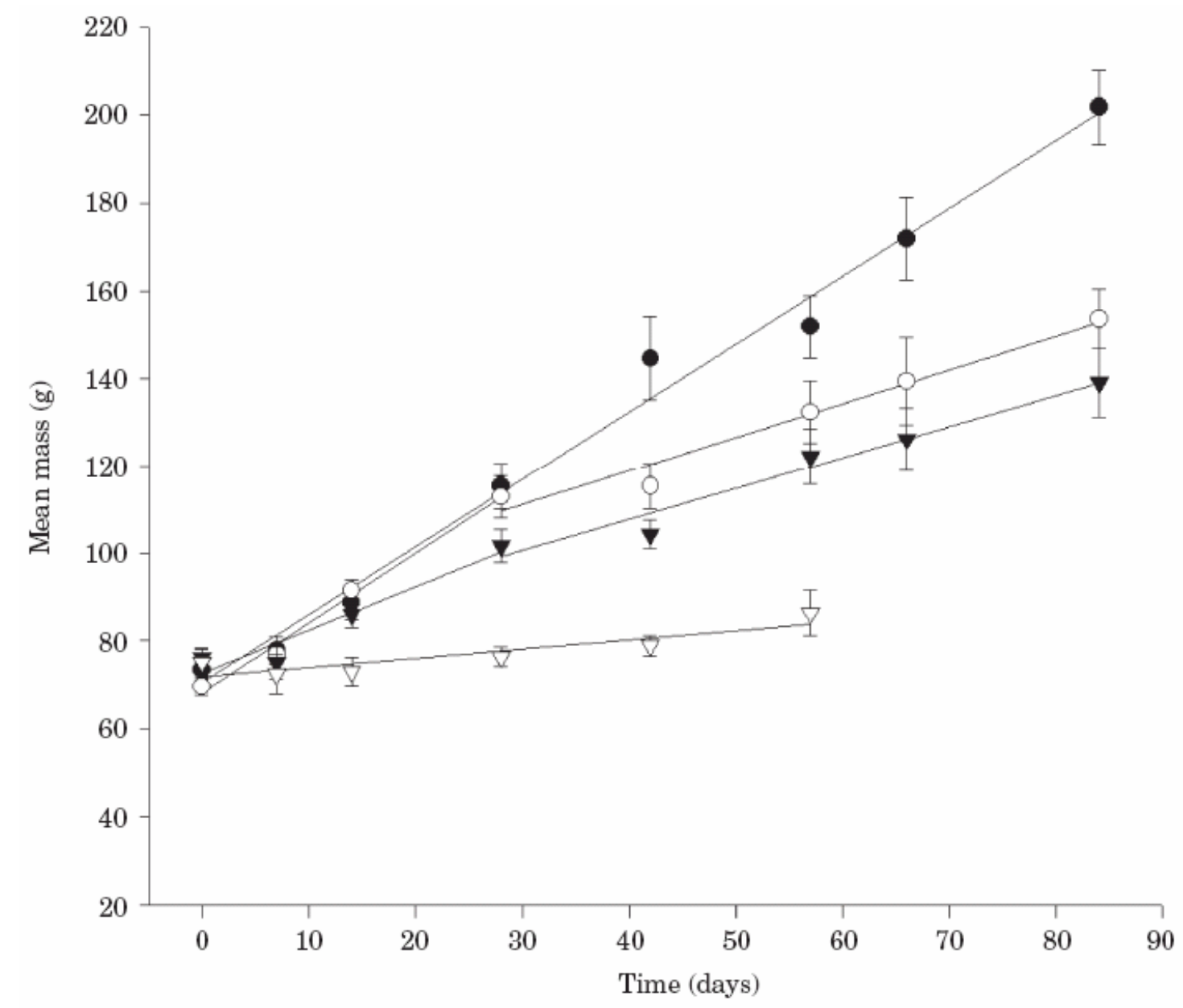

Plasma osmolarity and ionic concentrations are presented in Table I. After a week exposure, plasma osmolarity, $\mathrm{Cl}^{-}$and calcium concentrations were not significantly different from those of group C. Changes observed in $\mathrm{Na}^{+}$and $\mathrm{K}^{+}$means were of the same magnitude in $\mathrm{MH}$ and $\mathrm{H}$ groups with $\mathrm{Na}^{+}$slightly $(<5 \%)$ but significantly lower and $\mathrm{K}^{+}$significantly higher than in the control. By day 14, none of the parameters were significantly different from that of group C. By day 28, only $\mathrm{K}^{+}$was significantly increased in group $\mathrm{MH}$ whereas in group $\mathrm{H}$ (end of the experiment), all parameters except $\mathrm{Na}^{+}$were significantly different from that of group $\mathrm{C}$ : the increase in osmolarity 
(20 mOsmol) was concomitant to a marked increase in $\mathrm{K}^{+}$and total Ca concentrations (1.6 and 2.2 times higher respectively) and to a moderate but significant increase $(<5 \%)$ in $\mathrm{Cl}^{-}$. By day 57, plasma $\mathrm{Na}^{+}, \mathrm{Cl}^{-}$and $\mathrm{K}^{+}$concentrations in group $\mathrm{MH}$ were significantly higher than in group $\mathrm{C}$, these increases could account for the increase in osmolarity. Afterwards, the increases were moderate $\left(6 \mathrm{mOsmol} \mathrm{l}{ }^{-1}, 5 \mathrm{mM} \mathrm{Na}^{+}\right.$and 2 $\mathrm{mM} \mathrm{Cl}{ }^{-}$). Haematocrits were not different in $\mathrm{MH}$ and $\mathrm{H}$ groups (19-23\%) and control group (20-24\%).

Plasma cortisol concentrations showed a high intra-group variability (Table I). On day 7 and 14, they were higher in $\mathrm{MH}$ and $\mathrm{H}$ groups than in group $\mathrm{C}$, but differences were only significant on day 14 . By day 28, although cortisol concentrations of $\mathrm{MH}$ group were lower than by day 14, they remained significantly higher than in group C. In group $\mathrm{H}$, by day 28, 3 [cortisol] were around $200 \mathrm{ng} \mathrm{ml}^{-1}$ and 7 values were off scale of the RIA, and in group MH, by day 57, 2 [cortisol] were around 3 ng. $\mathrm{ml}^{-1}$, 4 around 60, 1 at 240 and 3 values were out of the RIA range.

Plasma TA-N and urea concentrations as a function of time are presented in Fig. 3. Plasma TA-N in H group increased regularly and reached $28 \mathrm{mg} \mathrm{l}^{-1}$ by day 28. In group $\mathrm{MH}$, there was a marked increase between day 0 and day 14 (5 times initial level) but afterwards it was regular and moderate (up to $21-22 \mathrm{mg} \mathrm{l}^{-1}$ by day $57-66$ ). In the two groups, no significant changes in plasma urea concentrations were observed by day 14 . In $\mathrm{H}$ group, there was a $77 \%$ increase between day 14 and day 28. In comparison, in MH group, urea concentrations were steady all over the experiment, and, except on day 57, they were not significantly different from those of group C. 
Fig. 3. Changes over time of plasma TA-N (A) and urea (B) in $\mathrm{C}(\boldsymbol{\odot}), \mathrm{MH}(\nabla)$ and $\mathrm{H}(\boldsymbol{\bullet})$ groups (C, 0.004; $\mathrm{MH}, 0.73$ and $\mathrm{H}, 0.88 \mathrm{mg} \mathrm{l}^{-1}$ ambient $\mathrm{NH}_{3}-\mathrm{N}$ concentrations). Values are means \pm standard error $(n=10)$. Superscript letters indicate inter-group statistical differences $(P<0.05)$ for one sampling date: means not sharing a common letter are significantly different. * indicates significant differences from the initial level (day 0) for each ambient concentration.
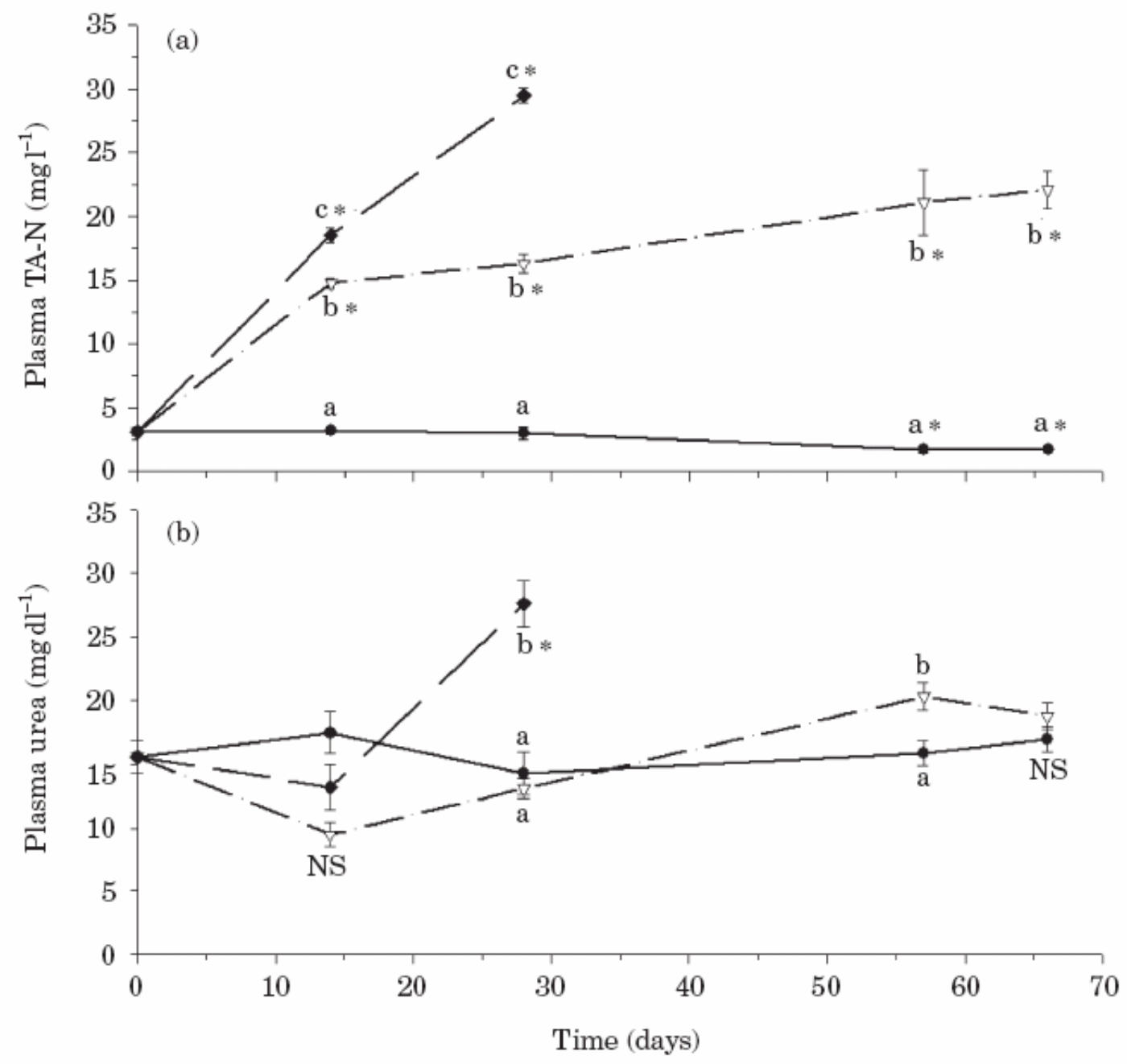
Table I. Comparison of plasma ions concentrations measured in turbot held under 0.88 and 0.73 mg ${ }^{-1}$ ambient $\mathrm{NH}_{3}-\mathrm{N}$ (groups $\mathrm{H}$ and $\mathrm{MH}$ respectively) with that of control (group C, $0.004 \mathrm{mg} \mathrm{l}^{-1}$ ambient $\mathrm{NH}_{3}-\mathrm{N}$ ) at different sampling dates.

\begin{tabular}{|c|c|c|c|c|c|c|c|}
\hline group & & day 0 & day 7 & day 14 & day 28 & day 57 & day 66 \\
\hline $\begin{array}{c}\mathrm{C} \\
\mathrm{MH} \\
\mathrm{H}\end{array}$ & $\begin{array}{l}\text { Osmolarity } \\
\left(\mathrm{mOsm} \mathrm{l}^{-1}\right)\end{array}$ & $324.1 \pm 2.5$ & $\begin{array}{l}324.3 \pm 2.3 \\
318.7 \pm 1.4 \\
318.0 \pm 1.5\end{array}$ & $\begin{array}{l}329.0 \pm 1.6 \\
322.5 \pm 2.1 \\
321.2 \pm 1.7\end{array}$ & $\begin{array}{l}327.7 \pm 1.0^{\mathrm{a}} \\
326.9 \pm 2.3^{\mathrm{a}} \\
347.9 \pm 5.0^{\mathrm{b}} *\end{array}$ & $\begin{array}{l}326.3 \pm 2.0^{\mathrm{a}} \\
348.8 \pm 7.5^{\mathrm{b}} *\end{array}$ & $\begin{array}{l}329.9 \pm 2.1^{\mathrm{a}} \\
354.6 \pm 4.2^{\mathrm{b}} *\end{array}$ \\
\hline $\begin{array}{c}\mathrm{C} \\
\mathrm{MH} \\
\mathrm{H}\end{array}$ & $\begin{array}{c}\mathrm{Cl}^{-} \\
\left(\mathrm{mmol} \mathrm{l}^{-1}\right)\end{array}$ & $139.5 \pm 1.2$ & $\begin{array}{l}141.0 \pm 1.3 \\
143.2 \pm 1.3 \\
141.7 \pm 0.7\end{array}$ & $\begin{array}{l}143.9 \pm 1.5 \\
143.5 \pm 0.8 \\
144.5 \pm 1.0\end{array}$ & $\begin{array}{l}143.7 \pm 0.9^{\mathrm{a}} \\
148.3 \pm 1.0^{\mathrm{ab}} \\
150.6 \pm 2.1^{\mathrm{b}^{*}}\end{array}$ & $\begin{array}{l}140.9 \pm 1.1^{\mathrm{a}} \\
153.8 \pm 3.7^{\mathrm{b}} *\end{array}$ & $\begin{array}{l}141.2 \pm 1.0^{\mathrm{a}} \\
155.1 \pm 2.1^{\mathrm{b}} *\end{array}$ \\
\hline $\begin{array}{c}\mathrm{C} \\
\mathrm{MH} \\
\mathrm{H}\end{array}$ & $\begin{array}{c}\mathrm{Na}^{+} \\
\left(\mathrm{mmol} \mathrm{l}^{-1}\right)\end{array}$ & $164.9 \pm 1.0$ & $\begin{array}{l}165.1 \pm 1.2^{\mathrm{a}} \\
157.1 \pm 1.2^{\mathrm{b}} \\
157.5 \pm 0.9^{\mathrm{b}} *\end{array}$ & $\begin{array}{l}162.2 \pm 1.1 \\
160.9 \pm 0.6 \\
158.1 \pm 1.3\end{array}$ & $\begin{array}{l}163.5 \pm 1.1 \\
160.6 \pm 1.1 \\
160.7 \pm 1.9\end{array}$ & $\begin{array}{l}164.6 \pm 0.9 \\
169.0 \pm 3.5\end{array}$ & $\begin{array}{l}163.3 \pm 0.7^{\mathrm{a}} \\
173.9 \pm 1.8^{\mathrm{b}} *\end{array}$ \\
\hline $\begin{array}{c}\mathrm{C} \\
\mathrm{MH} \\
\mathrm{H}\end{array}$ & $\begin{array}{c}\mathrm{K}^{+} \\
\left(\mathrm{mmol} \mathrm{l}^{-1}\right)\end{array}$ & $3.2 \pm 0.2$ & $\begin{array}{l}3.1 \pm 0.2^{\mathrm{a}} \\
4.2 \pm 0.5^{\mathrm{b}} \\
4.3 \pm 0.3^{\mathrm{b}}\end{array}$ & $\begin{array}{l}- \\
-\end{array}$ & $\begin{array}{l}3.7 \pm 0.2^{\mathrm{a}} \\
5.3 \pm 0.3^{\mathrm{b}} * \\
6.4 \pm 0.3^{\mathrm{c}} *\end{array}$ & $\begin{array}{l}2.6 \pm 0.3^{\mathrm{a}} \\
4.5 \pm 0.4^{\mathrm{b}}\end{array}$ & $\begin{array}{l}3.5 \pm 0.3 \\
4.0 \pm 0.4\end{array}$ \\
\hline $\begin{array}{c}\mathrm{C} \\
\mathrm{MH} \\
\mathrm{H}\end{array}$ & $\begin{array}{l}\text { Total Ca } \\
\left(\mathrm{mmol} \mathrm{l}^{-1}\right)\end{array}$ & $2.6 \pm 0.1$ & $\begin{array}{l}2.5 \pm 0.1 \\
2.6 \pm 0.2 \\
2.6 \pm 0.1\end{array}$ & $\begin{array}{l}2.5 \pm 0.3 \\
2.6 \pm 0.2 \\
2.8 \pm 0.3\end{array}$ & $\begin{array}{l}2.6 \pm 0.1^{\mathrm{a}} \\
2.4 \pm 0.1^{\mathrm{a}} \\
5.6 \pm 0.6^{\mathrm{b}} *\end{array}$ & $\begin{array}{l}2.6 \pm 0.1 \\
2.6 \pm 0.2\end{array}$ & - \\
\hline $\begin{array}{c}\mathrm{C} \\
\mathrm{MH} \\
\mathrm{H}\end{array}$ & $\begin{array}{l}\text { Cortisol } \\
\left(\mathrm{ng} \mathrm{ml}^{-1}\right)\end{array}$ & $1.8 \pm 0.7$ & $\begin{array}{l}1.7 \pm 0.8 \\
22.9 \pm 9.0 \\
17.7 \pm 6.7\end{array}$ & $\begin{array}{l}0.9 \pm 0.3^{\mathrm{a}} \\
41.6 \pm 11.0^{\mathrm{b}} \\
28.1 \pm 10.7^{\mathrm{b}}\end{array}$ & $\begin{array}{l}1.2 \pm 0.4^{\mathrm{a}} \\
14.7 \pm 5.5^{\mathrm{b}} \\
-\end{array}$ & $\begin{array}{l}3.0 \pm 0.7 \\
-\end{array}$ & - \\
\hline
\end{tabular}

Values are means \pm standard error $(\mathrm{n}=10)$. Superscript letters indicate inter-group statistical differences (P>0.05) for one sampling date: means without any letter or sharing a common letter are not significantly different. * indicates significant differences from the initial level (day 0) for each ambient concentration. 
EFFECTS OF AMMONIA EXPOSURES in L and M groups

Mass increases as a function of time are presented in Fig. 2. During first month growth rate was similar in $\mathrm{C}$ and $\mathrm{L}$ groups (mass gain was 1.55 and $1.59 \mathrm{~g} \mathrm{day}^{-1}$ respectively) while it was lower in $\mathrm{M}$ group (0.99 $\left.\mathrm{g} \mathrm{day}^{-1}\right)$. Afterwards growth rates declined but were not markedly dependent on ammonia concentration (0.77 and $0.71 \mathrm{~g}$ day $^{-1}$ for $\mathrm{L}$ and $\mathrm{M}$ groups respectively) and were stable until the end of the experiment. Final mean weights in L and M groups were not significantly different but they were 25 to $31 \%$ lower than those of group C.

No major change in osmolarity and hydromineral balance related to ammonia concentration and time was observed in $\mathrm{L}$ and $\mathrm{M}$ groups, except a transient decrease in $\mathrm{Na}^{+}$on day 7 in both groups and an increase in $\mathrm{K}^{+}$concentrations in M group from day 7 to day 57 (Table II). Haematocrits were not significantly affected by ammonia exposure: $18.8-19.2 \%$ in M group compared to 20-24\% in group C. Plasma cortisol in L group was in the same range as in control group, the transient increase observed on day 7 in M group was not significant due to the intra-group variability.

Plasma TA-N concentrations were significantly different from each other whatever the sampling date (Fig. 4A). In C group, there was a significant decrease after day 58 but the magnitude of the variation was small $\left(1.4 \mathrm{mg} \mathrm{l}^{-1}\right)$. In the 2 other groups, plasma TA-N concentrations increased during the first 28 days then they fluctuated around $6 \mathrm{mg}$ and $10 \mathrm{mg} \mathrm{l}^{-1}$ in $\mathrm{L}$ and $\mathrm{M}$ group respectively (2 and 3.5 times higher than control level). Plasma urea concentrations varied similarly in L and M groups (except on day 14) and were significantly lower (29 and 38\% respectively) than in C group (Fig. 4 B). 
Fig. 4. Changes over time of plasma TA-N (A) and urea (B) in C (O), L (O) and M ( $\mathbf{\nabla})$ groups (C, 0.004; L, 0.17; M, $0.34 \mathrm{mg} \mathrm{l}^{-1}$ ambient $\mathrm{NH}_{3}-\mathrm{N}$ concentrations). Values are means \pm standard error $(\mathrm{n}=10)$. Superscript letters indicate inter-group statistical differences $(\mathrm{P}<0.05)$ for one sampling date: means not sharing a common letter are significantly different. * indicates significant differences from the initial level (day 0) for each ambient concentration.
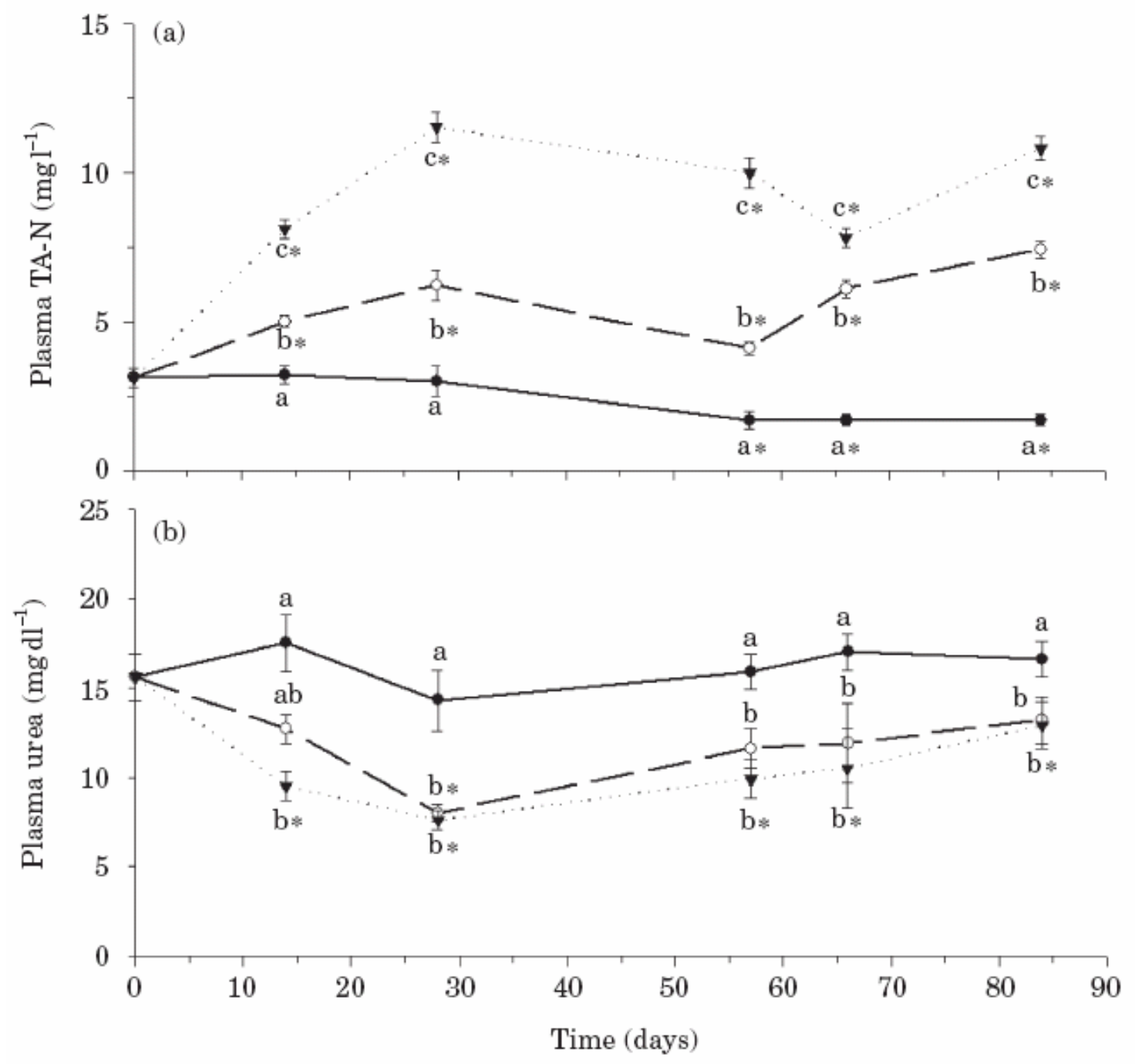
Table II. Comparison of plasma ions concentrations measured in turbot held under 0.17 and $0.34 \mathrm{mg} \mathrm{l}^{-1}$ ambient $\mathrm{NH}_{3}-\mathrm{N}$ concentrations (groups $\mathrm{L}$ and $\mathrm{M}$ ) with that of control (group C, $0.004 \mathrm{mg} \mathrm{l}^{-1}$ ambient $\mathrm{NH}_{3}-\mathrm{N}$ ) at different sampling dates.

\begin{tabular}{|c|c|c|c|c|c|c|c|c|}
\hline group & & day 0 & day 7 & day 14 & day 28 & day 57 & day 66 & day 84 \\
\hline $\mathrm{C}$ & Osmolarity & $324.1 \pm 2.5$ & $324.3 \pm 2.3$ & $329.0 \pm 1.6$ & $327.7 \pm 1.0$ & $326.3 \pm 2.0$ & $329.9 \pm 2.1$ & $326.9 \pm 1.5$ \\
\hline $\mathrm{L}$ & $\left(\mathrm{mOsm} \mathrm{l}^{-1}\right)$ & & $318.0 \pm 1.7$ & $319.6 \pm 1.3$ & $326.2 \pm 1.6$ & $319.6 \pm 2.1$ & $323.9 \pm 1.2$ & $324.0 \pm 2.0$ \\
\hline M & & & $319.7 \pm 1.4$ & $322.0 \pm 1.3$ & $322.4 \pm 1.3$ & $326.9 \pm 2.3$ & $319.0 \pm 1.5$ & $324.5 \pm 1.3$ \\
\hline $\mathrm{C}$ & & $139.5 \pm 1.2$ & $141.0 \pm 1.3$ & $143.9 \pm 1.5$ & $143.7 \pm 0.9$ & $140.9 \pm 1.1$ & $141.2 \pm 1.0$ & $144.5 \pm 0.6$ \\
\hline $\mathrm{L}$ & $\left(\mathrm{mmol}{ }^{-1}\right)$ & & $138.8 \pm 1.0$ & $139.6 \pm 0.6$ & $146.5 \pm 0.9 *$ & $139.1 \pm 1.3$ & $140.6 \pm 0.8$ & $144.4 \pm 0.5$ \\
\hline M & & & $139.6 \pm 0.7$ & $142.3 \pm 1.1$ & $144.6 \pm 0.7^{*}$ & $141.5 \pm 0.9$ & $138.9 \pm 1.3$ & $145.9 \pm 0.9$ \\
\hline $\mathrm{C}$ & & $164.9 \pm 1.0$ & $165.1 \pm 1.2^{\mathrm{a}}$ & $162.2 \pm 1.1$ & $163.5 \pm 1.1$ & $164.6 \pm 0.9$ & $163.3 \pm 0.7$ & $162.9 \pm 0.6$ \\
\hline $\mathrm{L}$ & $\left(\mathrm{mmol} \mathrm{l}^{-1}\right)$ & & $161.1 \pm 0.5^{\mathrm{ab}}$ & $159.3 \pm 0.9 *$ & $161.7 \pm 1.1$ & $161.2 \pm 1.5$ & $161.7 \pm 1.2$ & $161.9 \pm 1.0$ \\
\hline M & & & $158.6 \pm 0.8^{\mathrm{b}} *$ & $161.8 \pm 0.9$ & $159.3 \pm 1.3 *$ & $159.7 \pm 0.8^{*}$ & $157.7 \pm 2.1^{*}$ & $160.4 \pm 0.7 *$ \\
\hline $\mathrm{C}$ & $\mathrm{K}^{+}$ & $3.2 \pm 0.2$ & $3.1 \pm 0.2^{\mathrm{a}}$ & - & $3.7 \pm 0.2^{\mathrm{a}}$ & $2.6 \pm 0.3^{\mathrm{a}}$ & $3.5 \pm 0.3$ & $3.3 \pm 0.2$ \\
\hline $\mathrm{L}$ & $\left(\mathrm{mmol} \mathrm{l}^{-1}\right)$ & & $3.7 \pm 0.3^{\mathrm{ab}}$ & - & $4.1 \pm 0.1^{\mathrm{a}}$ & $2.9 \pm 0.3^{\mathrm{a}}$ & $3.7 \pm 0.4$ & $3.7 \pm 0.3$ \\
\hline $\mathrm{M}$ & & & $4.4 \pm 0.3^{\mathrm{b}} *$ & - & $4.9 \pm 0.3^{\mathrm{b}} *$ & $4.0 \pm 0.8^{b}$ & $3.8 \pm 0.3$ & $3.4 \pm 0.3$ \\
\hline $\mathrm{C}$ & Total Ca & $2.6 \pm 0.1$ & $2.5 \pm 0.1$ & $2.5 \pm 0.3$ & $2.6 \pm 0.1$ & $2.6 \pm 0.1$ & - & - \\
\hline $\mathrm{L}$ & $\left(\mathrm{mmol} \mathrm{l}^{-1}\right)$ & & $2.5 \pm 0.1$ & $2.4 \pm 0.1$ & $2.7 \pm 0.2$ & $2.3 \pm 0.1$ & - & - \\
\hline M & & & $2.6 \pm 0.2$ & $2.4 \pm 0.1$ & $2.4 \pm 0.1$ & $2.5 \pm 0.1$ & - & - \\
\hline $\mathrm{C}$ & Cortisol & $1.8 \pm 0.7$ & $1.7 \pm 0.8^{\mathrm{a}}$ & $0.9 \pm 0.3^{\mathrm{a}}$ & $1.2 \pm 0.4^{\mathrm{a}}$ & $3.0 \pm 0.7$ & - & $2.0 \pm 1.2$ \\
\hline $\mathrm{L}$ & $\left(\mathrm{ng} \mathrm{ml} \mathrm{l}^{-1}\right)$ & & $1.4 \pm 0.8^{\mathrm{a}}$ & $3.0 \pm 1.4^{\mathrm{a}}$ & $1.2 \pm 0.6^{\mathrm{a}}$ & $3.3 \pm 1.0$ & - & $3.0 \pm 0.8$ \\
\hline$M$ & & & $13.8 \pm 9.7^{\mathrm{a}}$ & $5.8 \pm 2.6^{\mathrm{a}}$ & $3.9 \pm 1.1^{\mathrm{a}}$ & $3.3 \pm 1.2$ & - & $2.3 \pm 0.9$ \\
\hline
\end{tabular}

Values are means \pm standard error $(n=10)$. Superscript letters indicate inter-group statistical differences $(\mathrm{P}>0.05)$ for one sampling date: means without any letter or sharing a common letter are not significantly different. * indicates significant differences from the initial level (day 0 ) for each ambient concentration. 
PLASMA TA-N AND UREA VARIATIONS AS A FUNCTION OF AMBIENT TA-N (C, L, $\mathrm{M}, \mathrm{MH}$ and $\mathrm{H}$ groups).

For each exposure date, plasma TA-N concentrations were positively correlated in a linear way to ambient TA-N concentrations (Fig. 5 left panel). On day 14, plasma TA-N concentration was higher than in seawater only in C group; it was equal to the isoconcentration (5.6 $\mathrm{mg} \mathrm{l}^{-1}$ ) in $\mathrm{L}$ group while in the other groups the plasma concentrations were lower than external concentrations. Slope of the equation increased with time, with internal TA-N concentrations very near seawater concentrations on day 57.

Plasma urea concentrations as a function of ambient TA-N are presented in Fig. 5 (right panel). On day 14, although they were lower in L and M groups than in C group, the range of fluctuations was not very large. The magnitude of variation was affected by exposure duration: plasma urea concentration was the lowest in $\mathrm{M}$ group and the highest in H group (day 28). In MH group they increased from day 28 to day 57, however they were back within the control range by day 66 as seen in Fig. 3B. 
Fig. 5. Plasma TA-N (left panel) and plasma urea (right panel) as a function of ambient TA-N. Ambient TA-N (Total Ammonia Nitrogen) concentrations were 0.16; 5.61; 11.42; 21.15 and $27.20 \mathrm{mg} \mathrm{l}^{-1}$ in groups $\mathrm{C}, \mathrm{L}, \mathrm{M}, \mathrm{MH}$ and $\mathrm{H}$ respectively. Regression equations (left panel) were calculated on day 14, 28 and 57 and can be compared to the isoconcentration equation $(\mathrm{x}=\mathrm{y})$ reported as a dashed line. The dashed horizontal line (right panel) indicates urea mean level in the control group.

AMMONIA CHRONIC TOXICITY IN TURBOT
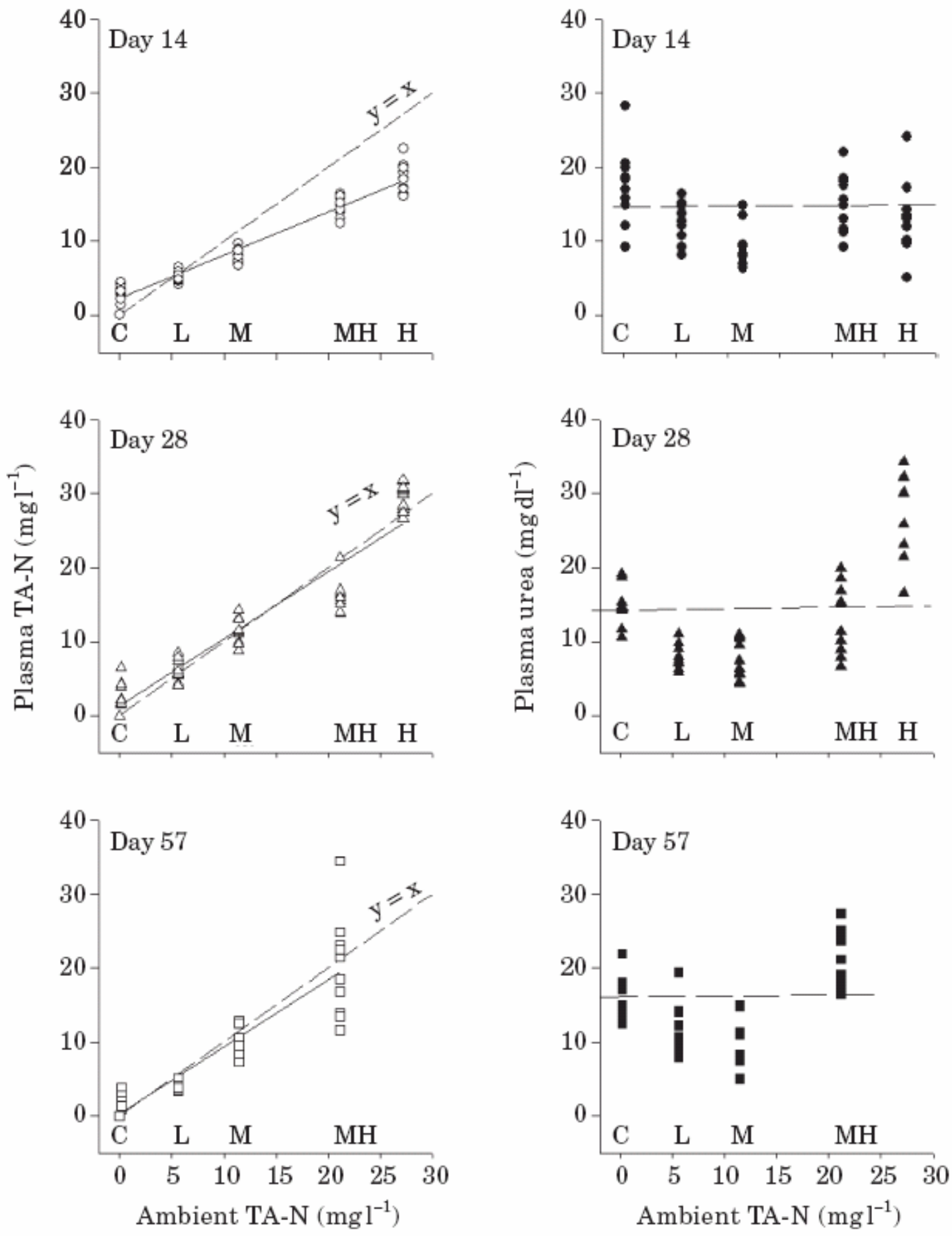


\section{DISCUSSION}

Growth rate measured in the $\mathrm{C}$ group was comparable to that found in turbot juveniles held under normoxic conditions (Pichavant et al., 2000, 2001). The $\mathrm{O}_{2}$ concentrations in water outflow $\left(\mathrm{O}_{2}>6 \mathrm{mg} \mathrm{l}^{-1}\right)$ were in the usual range measured in turbot farming and were over the threshold concentration decreasing growth in turbot (Pichavant et al. 2000, 2001), suggesting that the decreases in mass gains were due to ammonia exposure. However as exposure to ammonia could increase the metabolic demand it will be interesting to check if higher oxygen supply will modify growth results. Growth rates observed in $\mathrm{MH}$ and $\mathrm{H}$ groups are in accordance with results previously obtained under similar conditions where growth retardation was mainly explained by a decrease in food intake (Person-Le Ruyet et al., 1997a,b). The maintenance of a similar growth rate in $\mathrm{L}$ and $\mathrm{C}$ groups during the first month could reflect that food intake and conversion ratio were the same or that exposure to low ammonia concentration had a stimulatory effect on physiological functions. In Oncorhynchus mykiss, it has been shown (Linton et al., 1998) that low ammonia concentration may stimulate liver protein synthesis and even enhance growth depending on thermal regime. From day 28 to day 84 turbot of $\mathrm{L}$ and M groups had reduced but similar growth rates, a result that could be explained by a similar reduced appetite (food intake was about $15 \%$ lower than that of a control) as observed in turbot facing similar ammonia exposure (Person-Le Ruyet et al., 1997b). The time related effects observed on growth rate show that even when a minimal duration of exposure of one month is respected, as recommended by Kooijman \& Bedaux (1996) for toxicological studies, growth performances may not be the best indicator to estimate the effects of a pollutant such as ammonia. 
Results discussed below only reflect the effects of ammonia exposure as it has been clearly demonstrated (Pichavant et al., 2000, 2001) that in acclimated turbot, $\mathrm{O}_{2}$ concentrations as low as $3.5 \mathrm{mg} \mathrm{l}^{-1}$ have no effect on physiological indicators tested (TA-N, urea, cortisol, or ions). In C group, plasma TA-N concentration was higher than in water and in the range observed in many fish species (Wood, 1993) and in turbot (Person-Le Ruyet et al., 1998; Rasmussen \& Korsgaard, 1998). The positive correlation of plasma TA-N to ambient TA-N observed in this study is consistent with previous studies in fresh and seawater species for short-term (Wilson \& Taylor 1992; Person-Le Ruyet et al., 1995, 1998) and long-term exposure duration (Knoph \& Thorud, 1996; Person-Le Ruyet et al., 1997a). Although the mechanisms of gill ammonia excretion have been extensively studied, they remained controversial for a long period (Wood, 1993 and Wilkie, 1997 reviews). Ammonia transfer through the gill occurs predominantly via $\mathrm{NH}_{3}$ simple diffusion. The external-internal ammonia gradient observed in this study in $\mathrm{M}, \mathrm{MH}$ and $\mathrm{H}$ groups suggests that ammonia could enter mainly by diffusion. The initial decrease in plasma $\mathrm{Na}^{+}$concentrations could have different explanations. $\mathrm{NH}_{4}{ }^{+}$on the apical surface could enter the gill in place of $\mathrm{Na}^{+}$on either exchanger, thus reducing the $\mathrm{Na}^{+}$entry (Payan et al., 1984; Wilson \& Taylor, 1992). Another possibility is that there is a temporary increase in $\mathrm{Na}^{+}$excretion resulting from a change in the transepithelial potential through the gill (Zadunaisky, 1984) and/or by an activation of the $\mathrm{Na}^{+} / \mathrm{K}^{+}$-ATPase (Salama et al., 1999). The increase in $\mathrm{Na}^{+}$plasma concentration, concomitant to a $\mathrm{Cl}^{-}$increase observed after a delay in $\mathrm{H}$ and $\mathrm{MH}$ groups suggests a dysfunction of $\mathrm{Na}^{+} \mathrm{Cl}^{-}$extrusion through the gill.

Under conditions where ammonia excretion is difficult, increased urea production is a way of detoxifying ammonia (Mommsen \& Walsh, 1992; Wood, 1993; 
Wright \& Land, 1998). Urea is less toxic to fish than ammonia and can be easily excreted mainly by diffusion through gill membranes (even under high ambient ammonia concentrations) but its production has an energetic extra-cost. In this study, plasma urea concentrations (that reflect the balance between production and excretion) increased or decreased depending on ammonia exposure concentration and duration. In $\mathrm{L}$ and $\mathrm{M}$ groups, they were lower than in $\mathrm{C}$ group and such a decrease, under similar ammonia exposures, has been reported in turbot (Rasmussen \& Korsgaard, 1998) and in Atlantic salmon (Knoph \& Thorud, 1996). It may be explained by an increase in urea excretion as previously reported in turbot (Person-Le Ruyet et al., 1997a,b). Relationships between plasma urea concentrations and ambient TA-N are probably complex and specific studies will be necessary to clarify them, specially in turbot which have a higher urea excretion rate than most teleosts (Dosdat et al., 1996).

Disturbances in ion homeostasis have been reported in postsmolt Atlantic salmon exposed for 2-3 days to ammonia concentrations of $0.25 \mathrm{mg} \mathrm{l}^{-1} \mathrm{NH}_{3}-\mathrm{N}$ (Knoph \& Thorud, 1996) while under lower concentrations $\left(<0.10 \mathrm{mg} \mathrm{l}^{-1} \mathrm{NH}_{3}-\mathrm{N}\right)$, they can regulate hydromineral balance for at least five weeks (Knoph \& Olsen, 1994). In freshwater or seawater adapted rainbow trout, short-term exposure to $0.3-0.5 \mathrm{mg} \mathrm{l}^{-1}$ $\mathrm{NH}_{3}-\mathrm{N}$ did not markedly affect osmolarity, $\mathrm{Cl}^{-}, \mathrm{Na}^{+}$and amino-acid concentrations (Wilson \& Taylor, 1992; Vedel et al., 1998). In turbot, this study showed that changes in plasma osmolarity were dependent on exposure concentrations and duration, and were of small magnitude $(<10 \%)$. The driving force for $\mathrm{Na}^{+}$and $\mathrm{Cl}^{-}$excretion through the gill epithelium of seawater fish is the chloride transport which is $\mathrm{Na}^{+}$dependent (Zadunaisky, 1984). Present work does not allow to specify the failing step in the process of ion excretion observed in $\mathrm{H}$ and $\mathrm{MH}$ groups at days 28 and 57 respectively 
but the disfunctioning of ionoregulation could be considered as preceding signs of distress.

Under all ammonia concentrations tested, except the lowest, there was an extracellular $\mathrm{K}^{+}$increase from day 7 that was concentration dependent and modulated by exposure duration (peaking at day 28). It may be due to $\mathrm{K}^{+}$losses from different tissues as observed in the muscles of ammonia-exposed rainbow trout (Vedel et al., 1998). The increase in plasma total Ca concentrations observed in $\mathrm{H}$ group at day 28 (end of the experiment) could come from internal pool and/or from a disturbance of calcium exchanges through the gill and the gut. It could result from a decrease in the capacity of the Stannius corpuscles to secrete stanniocalcin, leading to a loss of control of calcium exchanges. In rivers where $\mathrm{NO}_{2}{ }^{-}$and ammonia concentrations were high, the Stannius corpuscles of roach Rutilus rutilus (L.) showed signs of hyperactivity or even presented pathological features (Lopez et al., 1989). Cortisol has been shown to stimulate calcium uptake (Flik \& Perry, 1989) and could also be responsible for plasma total Ca increase as high plasma calcium concentrations were observed in fish with high cortisol levels.

Ammonia exposure may act as a stressor and induce some adaptive endocrine responses and complex metabolic adaptations (Wendelaar Bonga, 1997; Mommsen et al., 1999). However, chronically elevated cortisol levels may become damaging for several physiological functions (e.g. suppression of the immune system) but generally a return to normal levels is observed when acclimation occurs. In the present study, there has been probably an initial release of cortisol in response to ammonia exposure but as the first sampling was on day 7 , it was not clearly detectable. However in group M, there was a gradual decrease of cortisol as a function of time suggesting that there had 
been a previous higher level. The pattern observed in $\mathrm{L}$ and $\mathrm{M}$ groups suggests that fish acclimated to the new environmental conditions as it has been shown in salmonids after a long-term exposure to similar ammonia concentrations (Knoph \& Olsen, 1994). The transient decline in plasma cortisol concentration observed in $\mathrm{MH}$ group could also be considered as a recovery; however the rise observed afterwards suggests that fish failed to acclimate. Plasma cortisol concentrations measured in the present study are difficult to compare to previous works where samplings were done during the first 48 hours of exposure (Tomasso et al., 1981; Spotte \& Anderson, 1989; Person-Le Ruyet et al., 1998). Turbot surviving to higher ammonia exposures than many fish species such as salmonids (US EPA, 1998; Person-Le Ruyet \& Boeuf, 1998), allowed to test a larger range for longer duration. The present work is, to our knowledge, the first time-course study of the variations of plasma cortisol concentrations during a sustained ammonia stress. As seen for ionic variations, it could be an indicator that fish fail to adapt to a specific ammonia level. This study highlights that turbot regulate their homeostasis even when they are maintained for long periods under $0.34 \mathrm{mg} \mathrm{l}^{-1} \mathrm{NH}_{3}-\mathrm{N}\left(11 \mathrm{mg} \mathrm{l}^{-1} \mathrm{TA}\right.$ $\mathrm{N}$ ), an ambient ammonia concentrations that could be encountered in turbot farming, corroborating results obtained in this species under different environmental stresses (Boeuf et al., 1999). Only fish facing the two lowest ammonia concentrations tested (0.17 and $0.34 \mathrm{mg} \mathrm{l}^{-1} \mathrm{NH}_{3}-\mathrm{N}$ ) can be considered acclimated, at least for all plasma parameters measured in this study. One important point is the duration of exposure, clearly evidenced by growth results. If the study had been run for one month the conclusion should have been that under $0.17 \mathrm{mg} \mathrm{l}^{-1} \mathrm{NH}_{3}-\mathrm{N}$, there was no ammonia effect and that threshold concentration for growth was $0.34 \mathrm{mg} \mathrm{l}^{-1} \mathrm{NH}_{3}-\mathrm{N}$. The present study shows that fish held under $0.17 \mathrm{mg} \mathrm{l}^{-1} \mathrm{NH}_{3}-\mathrm{N}$ cannot maintain their first month 
growth rate and suggests that they reached a physiological equilibrium, similar to that observed in $0.34 \mathrm{mg} \mathrm{l}^{-1}$ group, allowing them to grow at a similar rate. However, on a longer period or after any additional stress one may assume that they will probably respond differently.

This investigation was supported by a special-Ifremer grant: PR “ Régulation de la croissance chez les poissons ”. The authors thank L. Quéméner for help in statistical analysis. This study was covered by an appropriate licence to experiment on animals (reference 006443) delivered to first author by the Ministère de l'Agriculture, de la Pêche et de l'Alimentation (Paris, September 15, 1995).

\section{References}

Boeuf, G., Boujard, D. \& Person-Le Ruyet, J. (1999). Control of the somatic growth in turbot. Journal of Fish Biology 55 (Supplement A), 128-142. doi/jfbi.1999. 1057.

Dosdat, A., Servais, F., Métailler, R., Huelvan, C. \& Desbruyères, E. (1996). Comparison of nitrogenous losses in five teleost fish species. Aquaculture 141, 107127.

Fivelstad, S., Schwarz, J. \& Stromsnes, H. (1995). Sublethal effects and safe levels of ammonia in seawater for Atlantic salmon postsmolts (Salmo salar L.). Aquacultural Engineering 14, 271-280.

Flik, G. \& Perry, S. F. (1989). Cortisol stimulates whole body calcium uptake and the branchial calcium pump in freshwater trout. Journal of Endocrinology 120, 83-88.

Johansson, O. \& Wedborg, W. (1980). The ammonia-ammonium equilibrium in sea water at temperature between 5 and $25^{\circ}$ C. Journal of Solution Chemistry 91, 37-44.

Kooijman S. A. L. M. \& Bedaux, J. J. M. (1996). Analysis of toxicity tests in fish growth. Water Research 30, 1633-1644.

Knoph, M. B. (1992). Acute toxicity of ammonia to Atlantic salmon (Salmo salar L.) parr. Comparative Biochemistry and Physiology 101A, 272-282.

Knoph, M. B. \& Olsen, Y. A. (1994). Subacute toxicity of ammonia to Atlantic salmon (Salmo salar L.) in seawater: Effects on water and salt balance, plasma cortisol and plasma ammonia levels. Aquatic Toxicology 30, 295-310. 
Knoph, M. B. \& Thorud, K. (1996). Toxicity of ammonia to Atlantic salmon (Salmo salar L.) in seawater. Effects on plasma osmolality, ion, ammonia, urea and glucose levels and haematologic parameters. Comparative Biochemistry and Physiology 113A, 375-381.

Lamers, A. E., Flik, G., Atsma, W. \& Wendelaar Bonga, S. E. (1992). A rôle of diacetyl-alpha-melanocyte-stimulating hormone in the control of cortisol release in the teleost Oreochromis mosambicus. Journal of Endocrinology 135, 285-292.

Linton, T. K., Reid, S. D. \& Wood, C. M. (1998). The metabolic costs and physiological consequences to juvenile rainbow trout of a simulated winter warning in the presence or absence of sublethal ammonia. Transactions of the American Fisheries Society 127, 611-619.

Lopez, E., Luchetta, J. C. \& Peignoux, J. (1989). Réponses physiopathologiques des corspuscules de Stannius du gardon, Rutilus rutilus, à des perturbations de l'environnement. Bulletin Français de la Pêche et de la Pisciculture 315, 171-180.

Mommsen, T. P. \& Walsh, P. J. (1992). Biochemical and environmental perspectives on nitrogen metabolism in fishes. Experientia 48, 583-593.

Mommsen, T. P., Vijayan, M. M. \& Moon, T. W. (1999). Cortisol in teleosts: dynamics, mechanisms of action, and metabolic regulation. Reviews in Fish Biology and Fisheries 9: 211-268.

Payan, P., Girard, J. P. \& Mayer-Gostan, N. (1984). Branchial ions movements in teleosts: the roles of respiratory and chloride cells. In Fish Physiology (Hoar W. S. \& Randall D. J., eds.) pp. 39-63. New York and London: Academic Press.

Person-Le Ruyet, J., Baudin-Laurencin, F., Devauchelle, N., Métailler, M., Nicolas, J. L., Robin, J. \& Guillaume, J. (1991). In CRC Handbook of Mariculture, Volume II Finfish Aquaculture (McVey J. P., ed.) pp. 21-41. Boca Raton, FL: CRC Press.

Person-Le Ruyet, J., Chartois, H. \& Quémener, L. (1995). Comparative acute ammonia toxicity in marine fish and plasma ammonia response. Aquaculture 136, 181-194.

Person-Le Ruyet, J., Galland, R., Le Roux, A. \& Chartois, H. (1997a). Chronic ammonia toxicity in juvenile turbot (Scophthalmus maximus). Aquaculture 154, 155171. 
Person-Le Ruyet, J., Delbard, C., Chartois, H. \& Le Delliou, H. (1997b). Toxicity of ammonia to turbot juveniles: 1 . effects on survival, growth and food utilisation. Aquatic Living Resources 10, 307-314.

Person-Le Ruyet, J. \& Boeuf, G. (1998). L'azote ammoniacal, un toxique potentiel en élevage de poissons : le cas du turbot. Bulletin Français de la Pêche et de la Pisciculture 350-351, 393-412.

Person-Le Ruyet, J., Boeuf, G., Zambonino Infante, J., Helgason, S. \& Le Roux, A. (1998). Short-term physiological changes in turbot and seabream juveniles exposed to exogenous ammonia. Comparative Biochemistry and Physiology 119A, 511-518.

Pichavant, K., Person-Le Ruyet, J., Le Bayon N., Sévère, A., Le Roux, A., Quémener, L., Maxime V,. Nonnotte G. \& Boeuf, G. (2000). Effects of hypoxia on growth and metabolism of juvenile turbot. Aquaculture 188, 103-114.

Pichavant, K., Person-Le Ruyet, J., Le Bayon N., Sévère, A., Le Roux, A. \& Boeuf, G. (2001). Comparative effects of long-term hypoxia on growth, feeding and oxygen consumption in juvenile turbot and european sea bass. Journal of Fish Biology 59, 875-883. doi:10.1006/jfbi.2001.1702.

Rasmussen, R. S. \& Korsgaard, B. (1996). The effect of external ammonia on growth and food utilization of juvenile turbot (Scophthalmus maximus). Journal of Experimental Marine Biology and Ecology 205, 35-48.

Rasmussen, R. S. \& Korsgaard, B. (1998). Ammonia and urea in plasma of juvenile turbot (Scophthalmus maximus L.) in response to external ammonia. Comparative Biochemistry and Physiology 120A, 163-168.

Russo, R. C. \& Thurston, R. V. (1991). Toxicity of ammonia, nitrite and nitrate to fishes. Aquaculture and water quality. In Aquaculture and Water Quality (Brune E. \&. Tomasso J. R. eds.) pp. 58-59. Baton Rouge: World Aquaculture Society.

Salama, A., Morgan, I. J. \& Wood, C. M. (1999). The linkage between $\mathrm{Na}^{+}$uptake and ammonia excretion in rainbow trout: kinetic analysis, the effects of $\left(\mathrm{NH}_{4}\right)_{2} \mathrm{SO}_{4}$ and $\mathrm{NH}_{4} \mathrm{HCO}_{3}$ infusion, and the influence of gill boundary layer $\mathrm{pH}$. Journal of Experimental Biology 202, 697-709.

Spotte, S. \& Anderson, G. (1989). Plasma cortisol changes in seawater-adapted mummichogs (Fundulus heteroclitus) exposed to ammonia. Canadian Journal of Fisheries and Aquaculture Sciences 46, 2065-2069. 
Tomasso, J. R. (1994). Toxicity of nitrogenous wastes to aquaculture animals. Reviews in Fisheries Science 2, 291-314.

Tomasso, J. R., Davis, K. B. \& Simco, B. A. (1981). Plasma corticosteroid dynamics in channel catfish (Ictalurus punctatus) exposed to ammonia and nitrite. Canadian Journal of Fisheries and Aquatic Sciences 38, 1106-1112.

US EPA (United States Environmental Protection Agency) (1989). Ambient water quality criteria for ammonia (salt-water), EPA 440/5-88-0C. DC, 28 p.

US EPA (United States Environmental Protection Agency) (1998). Update of ambient water quality criteria for ammonia. EPA 822-R-98-008, 148 p.

Vedel, N. E., Korsgaard, B. \& Jensen, F. B. (1998). Isolated and combined exposure to ammonia and nitrite in rainbow trout (Oncorhynchus mykiss): Effects on electrolyte status, blood respiratory properties and brain glutamine/glutamate concentrations. Aquatic Toxicology 41, 325-342.

Wajsbrot, N., Gasith, A., Krom, M. D. \& Popper, D. M. (1991). Acute toxicity of ammonia to juvenile gilthead seabream Sparus aurata under reduced oxygen levels. Aquaculture 92, 77-288.

Wajsbrot, N., Gasith, A., Diamant, A. \& Popper, D. M. (1993). Chronic toxicity of ammonia to juvenile gilthead seabream Sparus aurata and related histopathological effects. Journal of Fish Biology 42, 321-328.

Wang, Y. \& Walsh, P. J. (2000). High ammonia tolerance in fishes of the family Batrachoididae (Toadfish and Midshipmen). Aquatic Toxicology 50, 205-219.

Wendelaar Bonga, S. E. (1997). The stress response in fish. Physiological Reviews 77, 591-625.

Wilkie, M. P. (1997). Mechanisms of ammonia excretion across fish gills. Comparative Biochemistry and Physiology 118A, 39-50.

Wilson, R. W. \& Taylor, E. W. (1992). Transbranchial ammonia gradients and acidbase responses to high external ammonia concentration in rainbow trout (Oncorhynchus mykiss) acclimated to different salinities. Journal of Experimental Biology 166, 95-112.

Wood, C. M. (1993). Ammonia and urea metabolism and excretion. In The Physiology of Fishes (Evans, D. H., ed.), pp. 379-425. Boca Raton, FL: CRC Press. 
Wright, P. A. \& Land, M. D. (1998). Urea production and transport in teleost fishes. Comparative Biochemistry and Physiology 119A, 47-54.

Zadunaisky, J. A. (1984). The chloride cell: the active transport of chloride and the paracellular pathways. In Fish Physiology (Hoar W. S.\& Randall D. J., eds.) pp. 129-176. 